\title{
An Analysis of Existential Anankastics: How to Get There from Here
}

\author{
Tom Werner \\ Carnegie Mellon University
}

\section{Introduction}

Nissenbaum (2005) shows that existential anankastic conditionals are a problem for many theories of anankastic conditionals. The problem stems from the existential quantification, because of which patently false or nonsensical sentences are predicted to be true. In particular, Nissenbaum discusses the sentence in (1).

(1) \#If you want to go to Harlem, you can kiss Pedro Martinez.

With respect to any plausible scenario we might construct, this sentence will be judged as deviant, but it turns out to be difficult to capture this deviance consistently across a range of scenarios in a possible worlds semantics.

The literature prior to Nissenbaum (2005) has concentrated on universal anankastic sentences, such as (2).

(2) If you want to go to Harlem, you have to take the A-train.

Here, the antecedent clause mentions a goal - getting to Harlem - and the consequent clause mentions a condition for achieving that goal - taking the Atrain. The condition is a necessary one, as indicated by the universal modal expression have to in the consequent. The sentence will be true just in case the addressee is at a location where the only available means of getting to Harlem is the A-train.

An existential version of this sentence is in (3).

(3) If you want to go to Harlem, you can take the A-train.

Again, the antecedent clause mentions the goal of getting to Harlem, and the consequent clause mentions taking the A-train as a condition for achieving that goal. The condition is no longer necessary, since the modal can is existential. Nissenbaum suggests that these conditionals be called sufficiency conditionals, given the idea that the condition expressed is sufficient for reaching the stated goal. At any rate, this sentence will be true just in case the addressee is at some location where the A-train is an available means of getting to Harlem.

In many theories of anankastic conditionals, including Nissenbaum's, the assumption has been that the ordering source is bouletic, relating to the addressee's wishes or desires. But now consider the problem raised by (1). 
Suppose the addressee is at some location from whence either the A-train or the C-train goes to Harlem, and that the baseball pitcher Pedro Martinez is on the Atrain. Suppose also that the addressee would like to kiss Pedro Martinez, given the chance. This wish will go into the bouletic ordering source, as will the stated goal of getting to Harlem. But now it turns out that if there is a best world in which the addressee gets to Harlem and kisses Pedro Martinez, the sentence is true. (1) comes out true, even though it is clearly not.

The solution given for existential anankastics in Nissenbaum (2005) relies on the idea that these sentences contain an implicit to-clause, which for Nissenbaum is a rationale clause. The content of the rationale clause is built into the truth conditions, and by this account, the action specified in the consequent clause must be carried out with the aim of reaching the stated goal. For (1), since Pedro Martinez wouldn't be kissed in order to get to Harlem, the sentence is ruled out.

In this paper, I will argue that the rationale clause account does not make the right predictions in all cases, and I will try to develop an analysis that does. According to my analysis, the ordering source for these conditionals is teleological-circumstantial, not bouletic. Wishes or desires don't enter into the picture. Second, I argue that these are not sufficiency conditionals, since the stated means in itself is not sufficient for reaching the goal. Rather, the stated means is a member of a set of means that, considered together, are necessary for reaching the goal. The essential idea is that the ordering source determines the set of worlds in the modal base where the goal is reached most economically or efficiently. In all these worlds, an appropriate means for reaching that goal has been employed, with the existential anankastic mentioning one of these appropriate means. I aim in this way to capture the idea of means to an end, which has proved to be somewhat hard to do in a possible worlds semantics.

\section{Problems With Universal Anankastic Conditionals}

Here, I review problems with anankastic conditionals that have been addressed in semantic theory, following Nissenbaum's (2005) discussion closely. There are two categories: problems with non-compatible goals and problems with compatible goals. These problems come about in conjunction with a bouletic ordering source and universal quantification. Problems with non-compatible goals occur when the addressee wants to do multiple things that are at odds with each other. True sentences are predicted not to be true because of interference from irrelevant, non-compatible goals. Problems with compatible goals occur when the addressee wants to do multiple things that are not at odds with each other. The problems come from fixes to the theory that try to bypass the bouletic ordering source. False sentences are predicted to be true when irrelevant, compatible goals bring the bypassed ordering source back into play.

Kratzer (1991, and elsewhere) shows that the interpretation of modals requires two conversational backgrounds. One motivation for these comes from the problem with incompatible goals. Consider a scenario in which someone 
wants to become popular, but does not want to go to the pub. Let there be an unalterable fact that one can become popular only by going to the pub. Given this scenario, the following sentence is false.

(4) You should go to the pub.

By Kratzer's analysis, the modal base for this sentence is circumstantial, selecting worlds on the basis of relevant facts. The ordering source is bouletic. It orders worlds according to the extent to which the addressee's desires are fulfilled in each world. Since the desires in this case conflict, it won't be the case that in all the best worlds, the addressee goes to the pub. (4) is predicted not to be true, and it isn't. ${ }^{1}$

A problem arises, as pointed out in Sæbø (2001), with anankastic conditionals such as (5) when interpreted with respect to the scenario just discussed.

(5) If you want to become mayor, you have to go to the pub regularly.

By Kratzer's theory of conditionals, the proposition that the addressee wants to become mayor is added to the modal base. The bouletic ordering source orders worlds according to the specified desires. This time the truth conditions predict (5) to be false because the best worlds are either worlds in which the addressee becomes mayor or in which the addressee does not go to the pub, but not both. But (5) is true.

Penka et al. (2004), as well as von Fintel and Iatridou (2004), propose a solution to this problem by which what is added to the modal base is the proposition that the addressee becomes mayor, not the proposition that the addressee wishes to become mayor. By the von Fintel and Iatridou (2004) proposal, the consequent of (5) contains an implicit to-clause, as shown in (6).

(6) [If you want to become mayor, you have to go to the pub regularly [to become mayor]].

Now, all the worlds under consideration are worlds in which the addressee becomes mayor. There aren't any worlds in which the addressee does not go to the pub, because going to the pub is required for becoming mayor. Because of what the implicit clause denotes, therefore, the ordering source is bypassed.

Huitink (2005), however, raises a problem for these approaches. Consider the following scenario. The addressee is at a location from which only the A-train goes to Harlem and in which the soccer player Ruud van Nistelrooy is on the Atrain. We suppose that the addressee would like to kiss the soccer player, given the chance. To interpret this sentence, we add to the modal base the proposition that the addressee goes to Harlem, and consider the bouletically best of these. The

\footnotetext{
${ }^{1}$ I assume a version of the theory in which quantification is over the set of best worlds from the modal base as determined by the ordering source.
} 
best worlds are all worlds in which the soccer player is kissed. The following sentence should therefore be true, even though it isn't.

$$
\text { \#If you want to go to Harlem, you have to kiss Ruud van Nistelrooy. }
$$

Because the goals are compatible, the ordering source has been brought back into play.

Two solutions to the compatible goals problem have been proposed. Huitink (2005) simplifies the ordering source, allowing that it only contain the proposition that the addressee gets to Harlem. von Stechow et al. (2005) propose a solution by which the ordering source is changed altogether, basing it on similarity to the actual world.

A final issue to be mentioned is the problem of means. In von Stechow et al. (2005), the following list of descending anankasticity is given.

(8) In order to go to Harlem,

- you have to take the A-train.

- you have to take a train.

-you have to wait.

-you have to breathe.

-you have to be a person.

As you go lower in the list, an anankastic reading is less and less possible. I have added acceptability judgments in parentheses after the last three sentences. But how is the concept of means to an end to be worked into a theory in which propositions are represented as sets of possible worlds?

\section{Nissenbaum's Sentence}

We return now to existential anankastics. Nissenbaum's sentence is repeated here.

\#If you want to go to Harlem, you can kiss Pedro Maritnez.

We are trying to rule this sentence out, given the scenario in which Pedro Martinez is on the A-train and either the A-train or the C-train goes to Harlem, and in which the addressee would like to kiss the baseball player. Going to Harlem and kissing the baseball player are compatible goals, in this situation, but we see that this sentence is a problem for the types of theories so far examined. It is a problem for theories which attempt to bypass the ordering source, since the best worlds in which the addressee goes to Harlem would presumably all be worlds in which the addressee kisses the baseball player. There will be some best worlds in which this happens. It is a problem for theories that simplify the ordering source, or change it, simply because it is hard to rule out worlds in which the addressee goes to Harlem, takes the A-train, and kisses the baseball player. 
Nissenbaum (2005) adopts the implicit to-clause proposal. The representation for (3) would be (9).

[If you want to go to Harlem, you can take the A-train [to go to Harlem]]

His proposal involves the idea that to-clauses are rationale clauses, based on sentences such as the following.

Veritek took the A-train to get to Harlem.

Here there is no modal, yet as Nissenbaum notes, the to-clause has a teleological interpretation. It describes the aims or intentions of Veritek, the agent of the Atrain taking event. The beliefs of the agent are central to this account, because undertaking some action in order to achieve an aim or desire involves believing that that action will lead to the fulfillment of that aim or desire.

As for (3), this sentence will be true just in case there is at least one best world in the modal base in which the addressee gets to Harlem and is the agent of an A-train taking event whose goal is to get the agent to Harlem. Implicitly, the addressee will have to believe that taking the train will get him or her to Harlem.

But now consider (1) again. This sentence will be true just in case there is at least one best world in the modal base in which the addressee gets to Harlem and is the agent of a Pedro Martinez kissing event whose goal is to get the agent to Harlem. Nissenbaum relates the unacceptability of (1) to the unacceptability of (11).

\#I kissed Pedro Martinez in order to go to Harlem.

The idea apparently is that no one would kiss Pedro Martinez in order to get to Harlem, as required by the truth conditions, because no one would believe that kissing that would help.

In assessing this solution, however, it is worth noting that to-clauses are no always rationale clauses. Consider the following sentence.

Veritek had to take the A-train to get to Harlem.

Suppose that the A-train did not go to Harlem. (10) could still be true, as long as Veritek believed that the A-train went to Harlem. (12), however, would not be true. Veritek's beliefs make no difference to the truth conditions of the sentence. All that matters is Veritek's location and the layout of the NYC transit system, matters of fact about the world.

The proposed truth conditions to not appear to make the right predictions consistently. Consider the following background facts for a test of the theory. Although water dousing is widely believed to be an effective method of finding water in the ground for digging a well, it isn't. The chances of finding water by digging randomly are the same as if dousing is used. 
But now suppose I utter the following sentence to a believer in water dousing.

If you want to find water, you can use a dousing rod.

By Nissenbaum's truth conditions, this sentence will be true just in case there is at least one best world in the modal base in which the addressee finds water, and in which the addressee is the agent of a water dousing event whose goal is to find water. But then (13) will be true, because the addressee believes in water dousing. The sentence, however, is false. The point is quite general - beliefs of the addressee do not have any bearing on the truth conditions of an existential anankastic. For example, if addressee beliefs were relevant, (3) could be true even in a case where the A-train didn't go to Harlem.

\section{A Theory of Universal Anankastic Conditionals}

The lesson I think we should take from the discussion of incompatible and compatible goals is that the ordering source involved in the interpretation of anankastic conditionals is not bouletic. Incompatible goals don't render sentences like (5), repeated here, false.

(5) If you want to become mayor, you have to go to the pub regularly.

What makes (5) true, if it is true, is a requirement external to the addressee and unrelated to addressee wishes or desires. On the other hand, compatible goals don't make sentences like (7) true.

(7) \#If you want to go to Harlem, you have to kiss Ruud van Nistelrooy.

(7) is false because kissing the soccer star won't get you to Harlem.

The problem with (7) and (1) is not that they are nonsensical but that they are false. For a comparison, consider (14).

(14) If you want to get back to Kansas, you can just click the heels of the Silver Shoes together.

(14) is to be interpreted with respect to a world in which different laws of physics apply. Given those different laws, (14) is true.

But the action suggested in the anankastic conditional must be more that just physically possible. Suppose Harlem is to the north, but I tell you,

(15) \#If you want to get to Harlem, you can take the B-train south.

Even if you could take the B-train one stop to the south before changing to the Atrain and going north again, I would not be taken as having spoken truthfully. 
What is wanted are the best means available, given a range of possibilities that are clear in the context.

My conclusion is that the interpretation of anankastic conditionals involves two ordering sources. One ordering source is circumstantial. It orders worlds according to whether or not basic physical laws are obeyed. The other ordering source is teleological. It orders worlds according to how well some goal is reached in terms of efficiency, economy, ease, and so on. To get the ordering sources to work together, I employ a ranking: $\mathrm{T}<\mathrm{C}$. The idea of ranking ordering sources is proposed in Werner (2005). According to that idea, a lower-ranked ordering source can only order worlds left as ties by a higher-ranked one. Here, the teleological source can only order worlds left as ties by the circumstantial ones. The result is that all T-best worlds will also be C-best worlds, worlds which adhere to basic physical laws.

Linking circumstantiality to the ordering source, however, means a change in the division of labor for conversational backgrounds. In Kratzer (1991) and elsewhere, a circumstantial modal reading is associated with a circumstantial modal base and an empty ordering source. For me, a circumstantial modal reading is associated with a modal base I call totally realistic up to the time of speech. Such a modal base selects a set of worlds that branch at the time of speech and with this device we capture the idea of future indeterminism (Werner 2003). The modal readings of interest in the current paper are teleological, meaning that the ordering source is teleological. Due to the ranking, a teleological ordering entails a circumstantial. The modal base, I assume, is totally realistic up to the time of speech. My assumptions about circumstantial modals and teleological modals are shown in Figure 1.

\begin{tabular}{|l|l|l|}
\hline & $\begin{array}{l}\text { circumstantial } \\
\text { modal } \\
\text { reading }\end{array}$ & $\begin{array}{l}\text { teleological } \\
\text { modal } \\
\text { reading }\end{array}$ \\
\hline modal base & $\begin{array}{l}\text { totally realistic } \\
\text { up to speech } \\
\text { time }\end{array}$ & $\begin{array}{l}\text { totally realistic } \\
\text { up to speech } \\
\text { time }\end{array}$ \\
\hline $\begin{array}{l}\text { ordering } \\
\text { source }\end{array}$ & circumstantial & $\begin{array}{l}\text { teleological < } \\
\text { circumstantial }\end{array}$ \\
\hline
\end{tabular}

Figure 1: Division of labor for modal readings.

The if-clause in anankastic conditionals I treat as a conventional device for temporarily adding a proposition the modal base. What is added is a set of worlds 
in which some goal or telos is achieved. The if-clause couches this speakernominated telos in terms of interests or desires of the addressee. However, I believe this is only one of a variety of devices with a similar semantic function, as I discuss in Werner (2005). Some others are illustrated in the following sentences.

(16) To get to Harlem, you have to take the A-train.

(17) In order to get to Harlem, you have to take the A-train.

(18) You have to take the A-train or you won't get to Harlem.

In these examples, to-clauses, in order to-clauses, and disjuncts are used respectively to nominate a telos. (Disjuncts state the complement of the telos.)

In any event, we arrive at the picture of possible worlds involved in the interpretation of an anankastic conditional shown in Figure 2. The totally realistic modal base up to the time of speech gives a set of world. The if-clause carves out a subset of these worlds in which the speaker-nominated telos is achieved. I call this set the enhanced modal base. The worlds are ordered, giving us a subset of Circumstantially-best worlds which itself is a superset of Teleologically-best worlds.

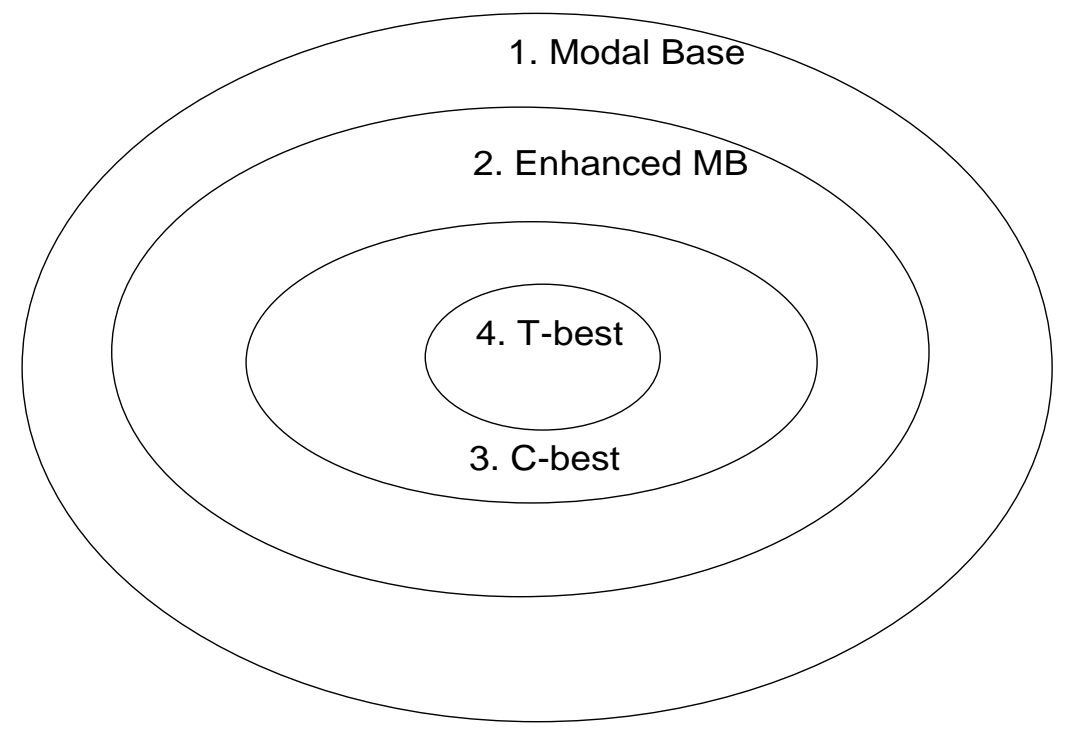

Figure 2: Subset relations.

Now I want to return to the issue of how to capture the idea of means to an end in a possible worlds semantics. In this connection, consider (19).

\#If you want to get to Harlem, you have to breathe. 
In (19) the consequent does not have an anankastic reading, which makes for a mismatch with the telic if-clause. My hunch about what is wrong with this sentence is that the denotation of the core proposition under the modal is too inclusive. It covers too much. Of course you breathe. But you breathe anyway just to stay alive, whether or not you get to Harlem by the most efficient means available.

The theoretical implementation of this hunch is a requirement that the core proposition be something true in all T-best worlds in the modal base where the specified goal is met, but not true in all C-best worlds where the goal is met. The hatch marks in Figure 3 show a denotation that is too inclusive, whereas the hatch marks in Figure 4 show one that is just right.

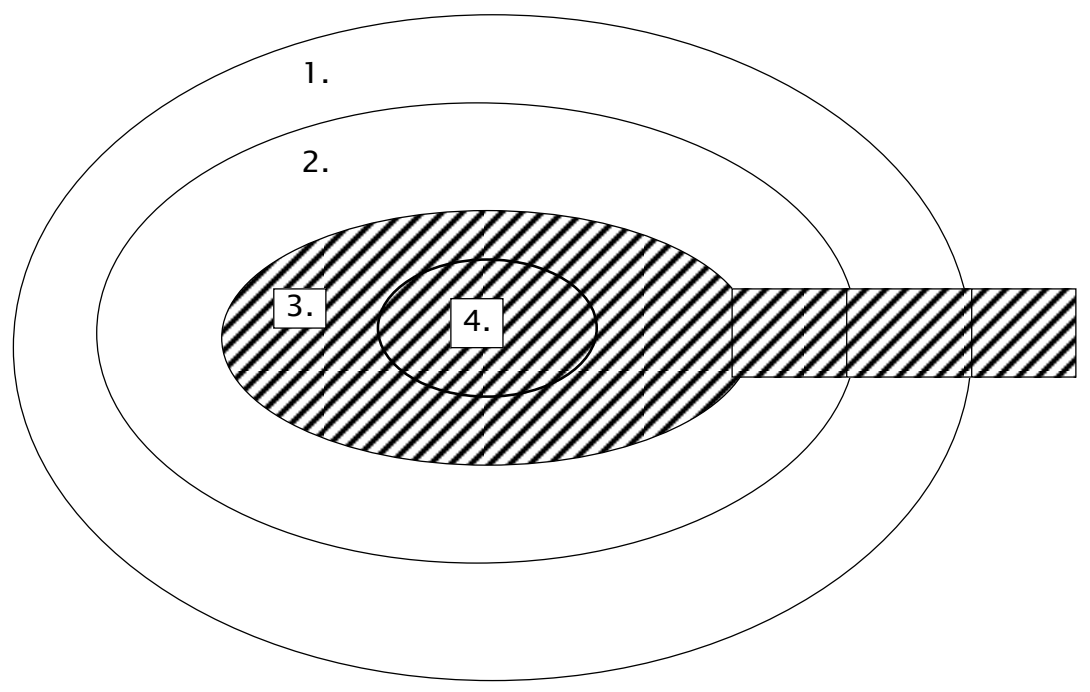

Figure 3: Denotation for core proposition which is too inclusive. 


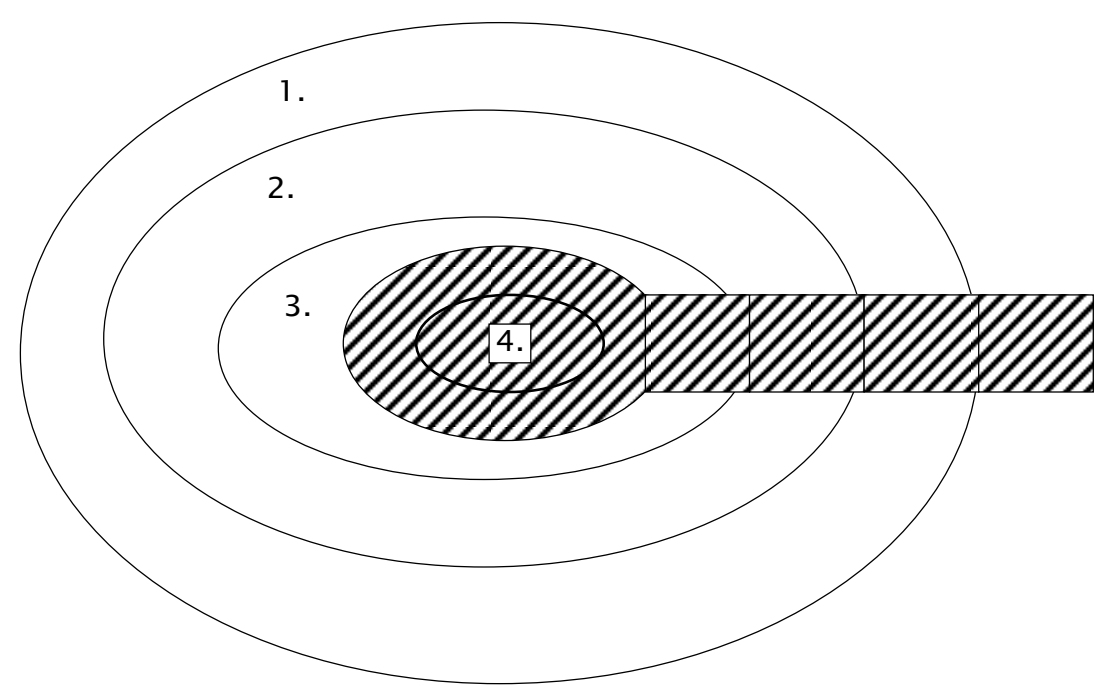

Figure 4: Denotation for core proposition of the right size. (20).

(20) 'If...want $p$, then must $q^{\text {' }}$ is true relative to modal base $f$ and ordering source $g_{i}$ iff

(i) $\llbracket q \rrbracket_{f, g i} \supseteq\left\{\mathrm{w} \in \mathrm{W}\right.$ : w is a $\mathrm{g}_{\mathrm{i}}\left(\mathrm{t}_{0}, \mathrm{w}_{0}\right)$-best world in $\left.\cap\left(\mathrm{f}\left(\mathrm{t}_{0}, \mathrm{w}_{0}\right) \cup \llbracket \mathrm{p} \rrbracket_{\mathrm{f}, \mathrm{gi}}\right)\right\}$;

(ii) $\llbracket q \rrbracket_{\mathrm{f}, \mathrm{gi}} \nsupseteq\left\{\mathrm{w} \in \mathrm{W}\right.$ : $\mathrm{w}$ is a $\mathrm{g}_{\mathrm{i}+1}\left(\mathrm{t}_{0}, \mathrm{w}_{0}\right)$-best world in $\left.\cap\left(\mathrm{f}\left(\mathrm{t}_{0}, \mathrm{w}_{0}\right) \cup \llbracket \mathrm{p} \rrbracket_{\mathrm{f}, \mathrm{gi}}\right)\right\}$

$\mathrm{f}$ is a totally realistic modal base for the time of speech that takes a time and world as arguments. $\mathrm{g}_{\mathrm{i}}$ is a teleological ordering source and $\mathrm{g}_{\mathrm{i}+1}$ is a circumstantial ordering source. The first clause says that the core denotes a superset of the T-best worlds in the enhanced modal base, and the second clause says that the core does not denote a superset of the C-best worlds in the enhanced modal base.

Before turning to existential anankastics, I turn to an issue that has been raised with respect to my theory. ${ }^{2}$ Consider the following sentence, for which no plausible reading seems available.

\#If you want to go to Harlem, you have to save time.

\footnotetext{
${ }^{2}$ This point was raised at the SALT 16 conference by Magdalena Schwager (pc) with respect to my theory of existential anankastics. Her point applies equally to my theory of universal anankastics, so I bring it up here. The example in (21) is hers, but with a modification of the modal force.
} 
In my theory, we consider worlds in which a goal is reached by some criteria of efficiency and in which basic physical laws are not violated. The requirement I have stated is that the core is not too inclusive, but at the same time it must include all teleologically best worlds. For (21), saving time certainly would be true in all teleologically best worlds but not in all the circumstantially best worlds where the goal of reaching Harlem is met. Therefore, my theory predicts (21) to be true.

The issue, apparently, is that the core proposition in (21) - that the addressee saves time - would already be in the ordering source. Having it appear again in the consequent renders the conditional completely uninformative. For a real-life analogy, suppose I want to buy a bicycle. I go to the Consumer Reports website, where all available bicycles are ranked in terms of cost, safety, reliability, and so on. The ranking yields information such as that Schwinn makes a pretty good bicycle, or that a decent bicycle will cost at least 500 dollars, and so on. The point is, I get information out that I didn't have to begin with. But suppose instead that I am told that the best bikes are reliable. I already knew that, because reliability was one of the criteria. Such a result would be completely uninformative. A modal or a conditional sentence is something like the Consumer Reports website. It gives information gleaned as the result of ordering possibilities, but to make any sense the information must go beyond what we started with.

Therefore, I add the requirement to my theory that the core proposition under the teleological modal cannot be in the teleological ordering source. This added requirement is in keeping with the original spirit of the theory, that anankastic conditionals provide information we didn't have to begin with: "If you want to get to Harlem quickly and cheaply, you take the A-train," but not, "If you want to get to Harlem quickly and cheaply, you go quickly and cheaply."

\section{A Theory of Existential Anankastic Conditionals}

To get an idea what is going on with existential anankastics, it is important to note that these are not sufficiency conditionals. Consider again (3), repeated here.

(3) If you want to go to Harlem, you can take the A-train.

Taking the A-train is not sufficient to get to Harlem. Other things also have to be true as well, for you to get to Harlem successfully: you have to stay on the train, you have to get off at the right stop, the train cannot derail, and so on.

What does seem to be true is that the conditional specifies one of several appropriate means for reaching the goal, and that all the appropriate means together will yield necessity. (3) is true in a scenario in which either the A-train or the C-train go to Harlem. If these are the only available means of getting there, (22) is also true.

If you want to go to Harlem, you have to take a train. 
What this suggests is that truth conditions for existential anankastics should combine in such a way that we get truth conditions for a universal, and conversely, truth conditions for a universal anankastic should come apart in such a way as to give truth conditions for existentials. To achieve this result, I will employ the notion of a supercover.

Simons (2005) defines a supercover S of a set A as a set of sets whose union is a superset of $\mathrm{A}$, and whose every member has a non-empty intersection with A. This is denoted $\mathrm{S} \supseteq_{\mathrm{sC}} \mathrm{A}$. Figure 5 illustrates such a relation between $\mathrm{S}$ and $\mathrm{A}$. (Note that there is no requirement that the subsets of $\mathrm{S}$ be disjoint.)

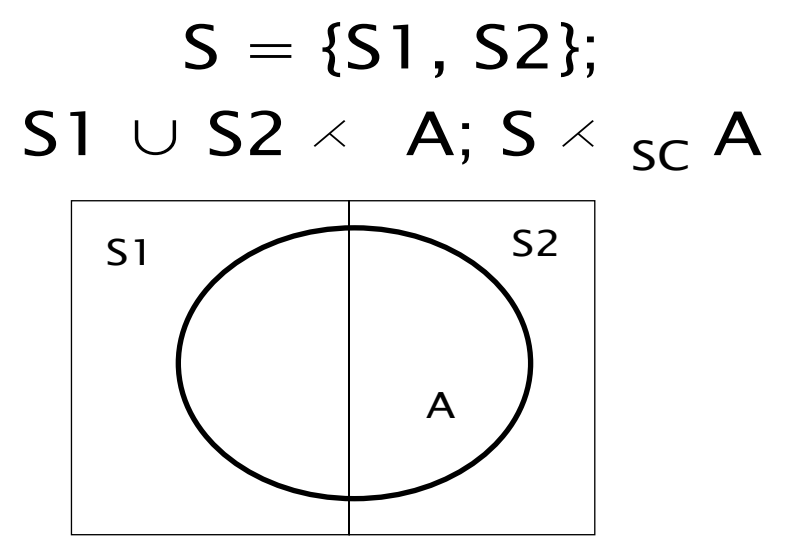

Figure 5: Illustration of supercover.

For existential anankastics, we need the core proposition to denote a member of a supercover over the set of T-best but not C-best worlds in the enhanced modal base.

A second point involves the fact that whether or not you kiss Pedro Martinez in the scenario presented has no bearing on your getting to Harlem or not. Kissing Pedro Martinez is not a means of getting to Harlem. If you get there, it's thanks to your employing a suitable means. The proposition that you kiss Pedro Martinez will be superfluous in a supercover of the sort we are looking for. We implement this idea by requiring the supercover to have no redundant members.

The truth conditions for an existential anankastic conditional can now be stated.

(23) 'If...want $p$, can q' is true relative to modal base $f$ and ordering source $g_{i}$ iff there is a set $\mathrm{S}$ such that:

(i) $\mathrm{S} \supseteq \mathrm{sC}\left\{\mathrm{w} \in \mathrm{W}\right.$ : $\mathrm{w}$ is a $\mathrm{g}_{\mathrm{i}}\left(\mathrm{t}_{0}, \mathrm{w}_{0}\right)$-best world in $\left.\cap\left(\mathrm{f}\left(\mathrm{t}_{0}, \mathrm{w}_{0}\right) \cup \llbracket \mathrm{p} \rrbracket_{\mathrm{f}, \mathrm{gi}}\right)\right\}$ and $\llbracket q \rrbracket_{f, g i}$ is a member of $S$; 
(ii) $\mathrm{S} \nsupseteq_{\mathrm{SC}}\left\{\mathrm{w} \in \mathrm{W}\right.$ : $\mathrm{w}$ is a $\mathrm{g}_{\mathrm{i}+1}\left(\mathrm{t}_{0}, \mathrm{w}_{0}\right)$-best world in $\left.\cap\left(\mathrm{f}\left(\mathrm{t}_{0}, \mathrm{w}_{0}\right) \cup \llbracket \mathrm{p} \rrbracket_{\mathrm{f}, \mathrm{gi}}\right)\right\}$;

(iii) $S \backslash \llbracket q \rrbracket_{f, g i} \nexists_{S C}\left\{\mathrm{w} \in \mathrm{W}\right.$ : $\mathrm{w}$ is a $\mathrm{g}_{\mathrm{i}}\left(\mathrm{t}_{0}, \mathrm{w}_{0}\right)$-best world in $\cap\left(\mathrm{f}\left(\mathrm{t}_{0}, \mathrm{w}_{0}\right) \cup\right.$ $\left.\left.\llbracket p \rrbracket_{f, g_{i}}\right)\right\}$;

(iv) $\mathrm{S}$ is a contextually salient alternative set.

The modal base $\mathrm{f}$ is totally realistic up to the time of speech. $\mathrm{g}_{\mathrm{i}}$ is the teleological ordering source and $\mathrm{g}_{\mathrm{i}+1}$ is the circumstantial ordering source.

The first clause of the truth conditions states that the supercover of which the core proposition is a member extends over the T-best worlds in the enhanced modal base. The second clause states that it doesn't extend over the C-best worlds in the enhanced modal base. The third clause ensures that the core proposition is not redundant. It must be such that if the core proposition were removed from S, the resulting set would no longer supercover the T-best worlds in the enhanced modal base. The fourth clause is needed to disallow ad-hoc supercovers.

We can first apply the truth conditions to the good sentence in (3), repeated here.

(3) If you want to go to Harlem, you can take the A-train.

We are evaluating the sentence with respect to a location where only the A-train

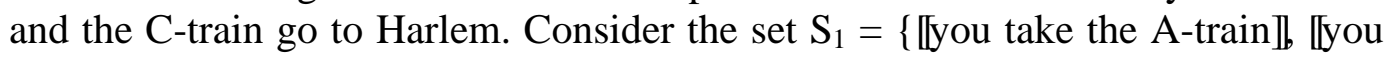
take the C-train $\mathbb{l}$. (I hereby suppress all indices and stick to a very informal presentation.) $S_{1}$ does supercover the set of T-best worlds in the enhanced modal base. $S_{1}$ doesn't supercover the set of C-best worlds in the enhanced modal base. If the proposition that you take the A-train were removed from $S_{1}$, the resulting set would no longer supercover the set of T-best worlds in the enhanced modal base. Finally, $\mathrm{S}_{1}$ is certainly a contextually salient alternative set. The truth conditions determine that the sentence is true, and this accords with our intuitions.

We turn to the bad sentence in (1), repeated here.

\#If you want to go to Harlem, you can kiss Pedro Martinez.

The claim is that we cannot find a set of sets $\mathrm{S}$ containing the proposition that you kiss Pedro Martinez that obeys the four clauses set down in the truth conditions. To show this, I will consider in turn several possible sets.

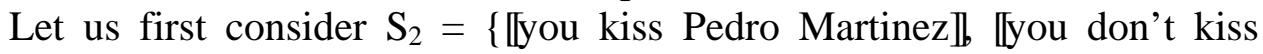
Pedro Martinez》 \}. $\mathrm{S}_{2}$ certainly does supercover the set of T-best worlds in the enhanced modal base, but it also supercovers the set of C-best worlds in the enhanced modal base. It is ruled out.

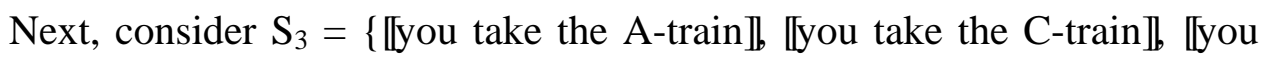
kiss Pedro Martinez $\mathbb{\mathbb { S }}$. $\mathrm{S}_{3}$ supercovers the set of T-best worlds in the enhanced modal base, but not the set of C-best worlds in the enhanced modal base. If we remove the proposition that you kiss Pedro Martinez from $S_{3}$, however, the resulting proposition still supercovers the set of T-best worlds in the enhanced modal base. The core proposition is redundant and consequently $S_{3}$ is ruled out. 
Finally consider the peculiar set $\mathrm{S}_{4}=\{\llbracket$ you kiss Pedro Martinez $\{\mathrm{w} \in \mathrm{W}$ : $\mathrm{w}$ is a T-best world in the enhanced modal base $\cap$ 【you don't kiss Pedro Martinez』\}. This set contains the proposition that you kiss Pedro Martinez and it contains the set of T-best worlds in the enhanced modal base in which you don't kiss Pedro Martinez. $\mathrm{S}_{4}$ will supercover the set of T-best worlds in the enhanced modal base because if a T-best world is one in which you kiss Pedro Martinez, it will be in the first set, and if it is one in which you don't kiss Pedro Martinez, it will be in the second set. $\mathrm{S}_{4}$ will not supercover the set of C-best worlds in the enhanced modal base. There will be a C-best world in the enhanced modal base that is not T-best and where you don't kiss Pedro Martinez. If you remove the proposition that you kiss Pedro Martinez from $\mathrm{S}_{4}$, you don't have a supercover over the T-best worlds in the enhanced modal base, because a T-best world in the enhanced modal base in which you do kiss Pedro Martinez is not in the second set in $S_{4}$. The first three clauses of the truth conditions are all obeyed. But $S_{4}$ is an odd set because its second member is odd. $\mathrm{S}_{4}$ is ruled out as not being a contextually salient alternative set.

We have been unable to find a set of sets containing the proposition that you kiss Pedro Martinez that satisfies all the clauses in the truth conditions in (23). If there is no such set, (1) is predicted to be false.

\section{Testing the Truth Conditions with Disjunctive Sentences}

Simons (2005) gives a theory for evaluating the so-called narrow reading for disjunction of modal sentences of the following form.

You have to $\mathrm{X}$ or you have to $\mathrm{Y}$.

The narrow reading for disjunction is the one that says for (24), in all best worlds, you either X or Y. By the theory in Simons (2005), the material in the disjuncts collectively denotes a supercover over best worlds in the modal base. But this gives us an opportunity to check our results from the last section and therefore to check each of the four clauses in our truth conditions.

We concluded that (3) was a good sentence because we found a set $\mathrm{S}_{1}=$

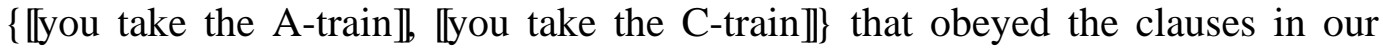
truth conditions for anankastic existentials in (23). Given Simons's theory of modal disjunctions, we predict that an anankastic disjunction in which each member of $S_{1}$ corresponds to a disjunct will be a good sentence. This prediction is borne out by (25).

(25) If you want to go to Harlem, either you have to take the A-train or you have to take the C-train.

In (25), the word either ensures an exhaustive reading of the disjuncts. The two disjuncts collectively form a supercover over the T-best worlds in the enhanced 
modal base which does not supercover the C-best worlds in the enhanced modal base. This is confirmation for the first clause in (23).

In evaluating (1), we tried to find a supercover of the right sort, but could

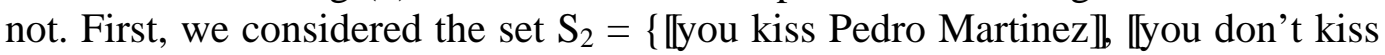
Pedro Martinez》\}. Our prediction will be that an anankastic disjunction in which each disjunct corresponds to one of the members of $S_{2}$ will be an unacceptable sentence. (26) bears this prediction out.

\#If you want to go to Harlem, you have to kiss Pedro Martinez or you have to not kiss him.

This is confirmation for the second clause in (23).

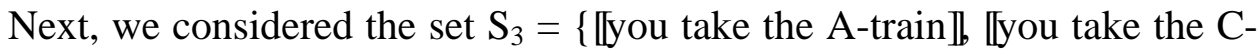

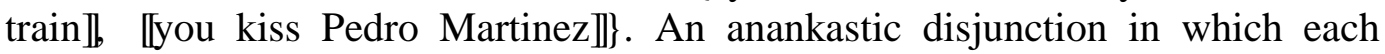
disjunct corresponds to a member of $S_{3}$ should be unacceptable. (27) bears out this prediction.

\#If you want to go to Harlem, you have to take the A-train, or you have to take the C-train, or you have to kiss Pedro Martinez.

This is confirmation for the third clause in (23).

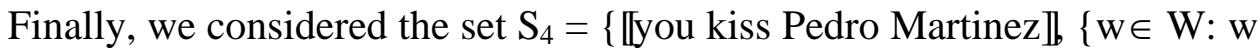
is a T-best world in the enhanced modal base $\cap$ 【you don't kiss Pedro Martinez $\mathbb{\|}$. It is simply not possible to find an anankastic disjunction in which the second disjunct corresponds to the second member of $\mathrm{S}_{4}$. This counts as confirmation of the fourth clause of the truth conditions in (23).

\section{Summary}

In the theory I have outlined in this paper, the evaluation of anankastic conditionals involves two kinds of ordering, teleological and circumstantial. Anankastic conditionals involve the consideration of some goal being reached. By a ranking between the ordering sources, the set of teleologically best worlds in which the goal is reached is a subset of the set of circumstantially best worlds in which the goal is reached, and a proper subset. The interpretation of the anankastic then requires a denotation which contains the subset but not the superset. If the anankastic is universal, we simply need the proposition under the modal to be of the right size. If the anankastic is existential, this proposition has to denote a member of a supercover of the right size. A leading idea in the paper is that a set of just the right size will contain only worlds in which the best available means has been employed, as long as we exclude sets that are themselves part of the teleological ordering source. 


\section{References}

von Fintel, Kai and Sabine Iatridou: 2004/2005, 'What to Do If You Want to Go to Harlem: Notes on Anankastic Conditionals and Related Matters', drafts at: [http:web.mit.edu/fintel/www/harlem.pdf]/ [http://mit.edu/fintel/ www/harlem-austin.pdf].

Huitink, Janneke: 2005, 'Anankastic Conditionals and Salient Goals', in E. Maier, C. Bary and J. Huintink (eds.) Proceedings of Sinn and Bedeutung 9.

Kratzer, Angelika: 1981, 'The Notional Category of Modality’, in H.-J. Eikmeyer and H. Rieser (eds.) Worlds, Words, and Contexts, Walter de Gruyter, Berlin, 38-74.

Kratzer, Angelika: 1991, 'Modality’, in A. von Stechow and D. Wunderlich (eds.) Semantics: An International Handbook, Walter de Gruyter, Berlin, 639650.

Nissenbaum, Jon: 2005, 'Kissing Pedro Martinez: (Existential) Anankastic Conditionals and Rationale Clauses', in E. Georgala and J. Howell (eds.) Proceedings of SALT XV, CLC Publications, Cornell University, Ithaca.

Penka, Krasikowa, Sveta Krasikowa, and Arnim von Stechow: 2004, 'The Meaning of German um zu: Necessary Condition and Enough/Too, draft at: [http://vivaldi.sfs.nphil.uni- tuebingen.de/arnim10/Handouts/ HandoutArnim6.pdf].

Sæbø, Kjell Johan: 2001, 'Necessary Conditions in a Natural Language', in C. Féry and W. Sternefeld (eds.) Audiatur Vox Sapientiae: a Festchrift for Arnim von Stechow, Akademie Verlag, Berlin, 472-449.

Simons, Mandy: 2005, 'Dividing Things Up: The Semantics of or and the Modal/or Interaction', Natural Language Semantics 13, 271-316.

von Stechow, Arnim and Sveta Krasikowa, and Dors Penka: 2005, 'Anankastic Conditionals', Ms., University of Tübingen: http://vivaldi.sfs.nphil.unituebingen.de/- arnim10/Aufsaetze/Nec.Cond6.pdf.

Werner, Tom: 2003, Deducing the Future and Distinguishing the Past. Temporal Interpretation of Modal Sentences in English. Doctoral Dissertation, Rutgers.

Werner, Tom: 2005, 'You Do What You Gotta Do, Or Why must Implies will', in E. Georgala and J. Howell (eds.) Proceedings of SALT XV, CLC Publications, Cornell University, Ithaca. 